\title{
PENGARUH SUHU TERHADAP PRODUKSI ASAM LEVULINAT DARI INULIN UMBI DAHLIA (Dahlia Sp.)
}

\author{
Rosa Murwindra, Saryono Sikumbang,Amir Awaluddin, Amilia Linggawati \\ FTK Universitas Islam Kuantan Singingi \\ FMIPA Universitas Riau \\ Email: rosamurwindra@gmail.com
}

\begin{abstract}
Dahlia is a floriculture plant with tuber that rich in inulin. Inulin is soluble in hot water and it will settle on cool temperature in alcohol. The inulin extraction to use hot water from dahlia tuber take from Bukittinggi of West Sumatra. Extraction result from $100 \mathrm{~g}$ dahlia tuber is $4 \%$ inulin ( $w / w$ dahlia tuber), such as inulin flour is white gray. As qualitative test with Seliwanoff and Nelson-Somogyi methods, that inulin positive contain of fructose and reducing sugar. This inulin can be converted into levulinic acid using acid catalyst at high temperature. Production of levulinic acid with variate reaction temperature from $130-170^{\circ} \mathrm{C}$. The reaction of inulin convertion is done in ampul that burned in oven. In this experiment, conversion of inulin to be levulinic acid is high 26,25\% (w/w inulin) using acid catalyst of hydrochloride acid $1 \mathrm{M}$ and heating $170{ }^{\circ} \mathrm{C}$ about 15 minutes.
\end{abstract}

Keywords: Dahlia tuber (Dahlia sp.), inulin, levulinic acid.

\section{PENDAHULUAN}

Tanaman dahlia memiliki bunga yang indah dengan warna-warni yang beragam. Tanaman dahlia tumbuh secara liar di pinggir jalan maupun di tanam di rumah-rumah penduduk serta ada yang di budidayakan untuk bunga hias. Namun, umbi dari tanaman dahlia tidak pernah dimanfaatkan kecuali sebagai bibit. Umbi dahlia yang tidak termanfaatkan ini biasanya akan menjadi limbah, padahal umbi dahlia merupakan sumber inulin yang paling baik, dengan kadar inulin sekitar $14 \%$ dari berat umbi (Hariono et al., 2009). Banyaknya inulin yang terdapat dalam umbi dahlia merupakan potensi besar untuk diolah menjadi platform chemical.

Salah satu contoh platform chemical adalah asam levulinat. Asam levulinat dapat digunakan dalam pembuatan berbagai senyawa kimia organik, polimer dan bermanfaat dalam industri farmasi (Bozell et al., 2000; Girisuta, 2007). Asam Levulinat diperoleh dari reaksi hidrolisis karbohidrat seperti selulosa, levulosa, inulin dan pati mengunakan katalis asam pada suhu tinggi. Polimer gula ini akan terdegradasi menjadi monomernya kemudian terbentuk zat antara hidroksi metil furfural (HMF) dan selanjutnya asam levulinat (Girisuta, 2007). Salah satu sumber derivat gula fruktosa adalah inulin. Oleh karena itu, inulin berpotensi dikembangkan untuk memproduksi asam levulinat.

Penelitian ini diawali dengan ekstraksi inulin dari umbi dahlia yang diperoleh di daerah Sumatra Barat Desa Kamang Hilir Kecamatan Kamang Magek Kabupaten Agam, Bukittinggi. Ekstraksi umbi dahlia dilakukan dengan cara pemanasan pada suhu $80-90{ }^{\circ} \mathrm{C}$, karena pada suhu $55{ }^{\circ} \mathrm{C}$ jumlah inulin yang larut hanya $5 \%$ (Simanjuntak et al. 2004). Menurut Robertfroid (2005) inulin hasil ekstraksi memiliki derajat polimerisasi (DP) lebih rendah dengan molekul linier rata-rata 12 dibandingkan dengan inulin yang diisolasi dari bakteri dengan rantai bercabang dan DP besar dari 1000. Selain itu, inulin lebih mudah dihidrolisis oleh asam dibandingkan dengan karbohidrat lain seperti selulosa dan pati (Barklay et al. 2010). Oleh karena itu, inulin hasil ekstraksi dari umbi dahlia relatif lebih mudah dikonversi menjadi asam levulinat.

Penelitian ini merupakan penelitian pendahuluan untuk mengkonversi inulin dari umbi dahlia menjadi asam levulinat. Reaksi hidrolisis dan konversi Inulin menjadi asam levulinat dipengaruhi oleh suhu, waktu dan konsentrasi katalis asam (Yan et al., 2008). Suhu memainkan peranan penting dalam menentukan seberapa cepat reaksi berlangsung. 
Suatu reaksi berlangsung lebih cepat pada suhu yang tinggi. Konversi inulin menjadi asam levulinat lebih mudah dilakukan pada suhu tinggi daripada suhu rendah. Girisuta (2007) melaporkan bahwa asam levulinat dihasilkan lebih banyak pada suhu yang tinggi dengan waktu reaksi yang lebih singkat menggunakan asam encer. Berdasarkan penelitian Yan et al (2008), hasil asam levulinat semakin tinggi dengan naiknya suhu reaksi, namun pada suhu reaksi tertentu asam levulinat yang dihasilkan berubah menjadi lakton dan humin. Oleh karena itu, pada penelitian ini untuk memproduksi asam levulinat dilakukan variasi parameter yang dapat mempengaruhi proses hidrolisis dan konversi inulin yaitu variasi suhu reaksi dari $130^{\circ} \mathrm{C}, 140^{\circ} \mathrm{C}, 150^{\circ} \mathrm{C}, 160^{\circ} \mathrm{C}, 170^{\circ} \mathrm{C}$, dengan menggunakan katalis asam klorida $(\mathrm{HCl}) 0,1 \mathrm{M}$ dan waktu reaksi 15 menit.

Tujuan pada penelitian ini adalah ekstraksi inulin dari tanaman umbi dahlia, analisis pengaruh suhu reaksi terhadap konsentrasi glukosa, fruktosa, asam levulinat, asam formiat dan memberikan informasi awal proses produksi asam levulinat dari inulin hasil ekstraksi umbi dahlia menggunakan katalis asam klorida.

\section{METODOLOGI PENELITIAN}

Bahan-bahan yang digunakan adalah umbi dahlia, etanol pa $96 \%$, arang aktif, asam klorida $(\mathrm{HCl})$, asam levulinat, asam formiat, glukosa, fruktosa, $\mathrm{H}_{2} \mathrm{SO}_{4}$, aquabides, air $\mathrm{RO}$ (reverse osmosis), reagen seliwanoff dan reagen NelsonSomogyi.

Alat-alat yang digunakan adalah blender, oven, ayakan 100 mesh, termometer, hot plate Cimarec Bornstead Thermolyne, timbangan Kern ALJ-220-4, HPLC (Hitachi) yang terdiri dari: pompa L-2130, kolom asam organik Aminex HPX-87H, kolom oven L-2300, auto sampler L-2200, detektor refraktif indeks, alat penghilang gas (degasser) Elmasonic S 100H (Elma), penyaring Sartorius Sedim (Biotech) Gettingan Germany, sentrifus mikro, sentrifus IEC Centra CLt International Equipment Company, dan peralatan gelas yang biasa digunakan dalam penelitian.
Umbi dahlia dibersihkan dari tanah yang melekat, dikupas, dicuci, dipotong-potong kecil dan ditimbang. Potongan umbi diblender dengan penambahan air 1:2 (b/v), lalu dipanaskan pada penangas air hingga suhu 80$90{ }^{\circ} \mathrm{C}$, selama \pm 30 menit. Setelah dingin, campuran disaring dengan kain dan diambil filtratnya. Filtrat yang diperoleh diukur volumenya dan ditambahkan etanol $30 \%$ sebanyak $40 \%$ dari total volume filtrat. Larutan disimpan dalam freezer pada suhu $\pm-4{ }^{\circ} \mathrm{C}$ selama 18 jam, untuk mengendapkan inulin. Endapan yang terbentuk dikeluarkan dan dibiarkan pada suhu ruang selama \pm 2 jam. Setelah endapan mencair lalu disentrifugasi $1500 \mathrm{rpm}$ selama 15 menit, sehingga diperoleh endapan inulin. Endapan inulin selanjutnya ditambah air dengan perbandingan 1:2 (b/v), kemudian dipanaskan pada penangas air hingga suhu $60-70{ }^{\circ} \mathrm{C}$ selama \pm 30 menit. Ke dalam larutan ini ditambahkan karbon aktif sebanyak $1-2 \%(b / v)$. Selanjutnya larutan disaring, diukur volumenya dan filtrat yang diperoleh ditambah etanol $30 \%$ sebanyak $40 \%$ dari total volume filtrat dan didinginkan dalam freezer selama \pm 18 jam. Setelah pendinginan tahap II ini endapan yang terbentuk dikeluarkan dan dicairkan pada suhu ruang \pm 2 jam, kemudian disentrifugasi $1500 \mathrm{rpm}$ selama 15 menit. Hasil sentrifugasi berupa endapan putih inulin dikeringkan di udara terbuka, sehingga diperoleh tepung inulin. Tepung inulin yang diperoleh diuji dengan reagen seliwanof untuk memastikan adanya gula fruktosa dan Nelson Somogyi untuk memastikan adanya gula pereduksi. Tepung inulin yang positif mengandung gula pereduksi dikonversi menjadi asam levulinat pada variasi suhu reaksi 130-170 ${ }^{\circ} \mathrm{C}$, menggunakan katalis asam klorida $0,1 \mathrm{M}$ dan waktu reaksi 15 menit.

Variasi Suhu Reaksi. Larutan induk substrat inulin dibuat dengan perbandingan zat padat dan zat cair 1:20 (5\% substrat) dengan cara melarutkan $1 \mathrm{~g}$ inulin dalam $20 \mathrm{ml}$ larutan katalis. Konsentrasi larutan katalis asam klorida dibuat konstan yaitu $0,1 \mathrm{M}$. Sebanyak 5 buah ampul diisi dengan $\pm 1 \mathrm{ml}$ larutan substrat. Ujung ampul dibakar sampai tertutup rapat. 
Masing-masing ampul dipanaskan dalam oven pada variasi suhu yaitu : $130 ; 140 ; 150 ; 160$ dan $170{ }^{\circ} \mathrm{C}$ selama 15 menit. Setiap ampul yang dikeluarkan dicelupkan ke dalam air es untuk menghentikan reaksi. Larutan dikeluarkan dari ampul, dipindahkan ke dalam ependorf dan disimpan dalam pendingin untuk selanjutnya dianalisis dengan HPLC. Larutan sampel sebanyak $200 \mu$ dimasukkan dalam micro tube dan diencerkan dengan menambahkan $1800 \mu 1$ air RO (reverse osmosis). Larutan disentifus dengan kecepatan 13000 rpm selama 15 menit. Sebanyak $400 \mu l$ larutan supernatan dipipet ke dalam botol vial kemudian diinjeksikan ke dalam HPLC. Konsentrasi masing-masing sampel dihitung dengan membandingkan luas area yang diperoleh pada kromatogram HPLC dengan kurva standar dari setiap senyawa glukosa, fruktosa, asam levulinat dan asam formiat. Penentuan konsentrasi asam levulinat sebagai berikut:

Kadar asam levulinat $(\%)=\frac{\text { Konsentrasi asam levulinat hasil reaksi }\left(\frac{\mathrm{mg}}{\mathrm{mL}}\right)}{\text { Konsentrasi inulin }\left(\frac{\mathrm{mg}}{\mathrm{mL}}\right)}$

\section{HASIL DAN PEMBAHASAN}

Ekstraksi dari 100 g umbi dahlia menghasilkan tepung inulin sebanyak $4 \%$ berat basah. Inulin diperoleh dengan cara pemanasan parutan umbi dahlia dengan air $1: 2(\mathrm{~b} / \mathrm{v})$, suhu 80-90 ${ }^{\circ} \mathrm{C}$ selama 30 menit. Pemanasan bertujuan untuk melarutkan inulin yang terkandung di dalam umbi karena inulin bersifat larut dalam air panas dan hanya sedikit larut dalam air dingin atau alkohol (Hariono et al. 2009). Larutan umbi yang telah dingin disaring dan diperoleh filtrat berwarna coklat gelap. Warna yang terbentuk pada larutan inulin ini terjadi karena adanya reaksi Maillard. Reaksi Maillard adalah reaksi antara karbohidrat (khususnya gula pereduksi) dengan gugus amina primer yang menghasilkan warna coklat. Proses pencoklatan dapat disebabkan karena substrat, enzim, suhu dan waktu. Gula-gula nonreduksi (seperti sukrosa) tidak bereaksi dengan protein pada suhu rendah, tetapi pada suhu tinggi terjadi pemecahan ikatan glikosidik dari sukrosa yang menghasilkan glukosa dan fruktosa. Glukosa dan fruktosa tersebut memiliki sifat pereduksi sehingga dapat melangsungkan reaksi Maillard (Widowati et al. 2005), sedangkan sukrosa tidak memiliki sifat pereduksi (Winarno 1997).

Etanol digunakan sebagai pelarut karena lebih selektif, netral dan dapat bercampur dengan air. Disamping itu, selain dapat mengendapkan inulin dari larutan, etanol juga dapat menyebabkan protein dan zat-zat warna ikut terekstrak. Filtrat yang telah dipresipitasi dengan etanol, disimpan pada suhu rendah. Menurut Rahayuningsih dan Purnawati (1993) bila larutan tersebut disimpan pada suhu rendah $\pm-4^{\circ} \mathrm{C}$ selama 18 jam, akan membentuk endapan putih yang disebut sebagai inulin. Untuk memisahkan endapan tersebut, filtrat yang telah dipresipitasi dan didinginkan, dibiarkan mencair pada suhu ruang selama \pm 2 jam kemudian disentrifugasi. Endapan hasil sentrifus ini berwarna putih kecoklatan (endapan inulin).

Endapan kemudian dipanaskan kembali dengan air $1: 2(\mathrm{~b} / \mathrm{v})$, suhu $60-70^{\circ} \mathrm{C}$ selama 30 menit. Pemanasan ulang bertujuan agar inulin dapat terlarut kembali dalam air serta dapat mendenaturasi protein yang dapat menyebabkan reaksi pencoklatan (browning). Setelah proses pemanasan ulang, larutan inulin ditambahkan arang aktif yang berfungsi sebagai bleaching agent untuk mengurangi warna coklat yang terbentuk. Pada penelitian yang dilakukan oleh Andyani (2001), penambahan arang aktif sebanyak 1-2\% (b/v) mempengaruhi perbedaan penampakan warna inulin. Inulin yang diekstraksi dengan penambahan arang aktif berwarna lebih putih daripada inulin yang tidak ditambahkan arang aktif. Hal ini karena pada saat pemucatan semua komponen warna seperti tannin, serta komponen karbonil yang sangat berperan dalam reaksi pencoklatan (browning) terikat dalam arang aktif, sehingga komponen pemberi warna dalam larutan dapat diminimalisir (Andyani 2001). Setelah arang aktif ditambahkan, larutan didinginkan, kemudian disaring. Filtrat yang diperoleh ditambahkan etanol $30 \%$ sebanyak $40 \%$ dari total volume filtrat dan didinginkan kembali. Proses pemisahan inulin dengan cara sentrifugasi diulangi kembali sehingga didapat 
endapan yang lebih bersih (inulin hasil ekstraksi). Endapan ini kemudian dikeringkan di udara terbuka lalu dihaluskan sampai berbentuk bubuk.

Inulin yang dihasilkan dari proses ekstraksi umbi dahlia berwarna putih abu-abu. Pada tepung inulin dilakukan uji Seliwanoff dan Nelson-Somogyi, dapat dilihat pada Tabel 1 . Berdasarkan uji seliwanoff terhadap inulin hasil ekstraksi umbi dahlia memperlihatkan perubahan warna yang begitu cepat dari bening menjadi merah bata setelah dipanaskan dalam air mendidih. Hal ini mengindikasikan bahwa inulin yang diekstraksi dari umbi dahlia pada penelitian ini adalah positif merupakan polifruktosa. Pada penentuan gula reduksi dengan metode Nelson-Somogyi dilakukan dengan menambahkan reagen Nelson-Somogyi dan dipanaskan dalam air mendidih selama 20 menit memberikan warna merah bata, kemudian ditambahkan reagen Arsenomolibdat membentuk kompleks molibden blue yang berwarna biru. Hal ini mengindikasikan bahwa inulin yang diekstraksi dari umbi dahlia positif mengandung gula-gula pereduksi.

Tabel 1. Uji Seliwanoff dan Nelson-Somogyi

\begin{tabular}{llll}
\multicolumn{4}{c}{ Tepung Inulin } \\
\hline Jenis uji & $\begin{array}{l}\text { Warna } \\
\text { larutan } \\
\text { inulin }\end{array}$ & $\begin{array}{l}\text { Warna } \\
\text { inulin }+ \\
\text { reagen }\end{array}$ & Hasil uji \\
\hline Seliwanoff & Bening & $\begin{array}{l}\text { Merah } \\
\text { jingga }\end{array}$ & $\begin{array}{l}\text { Fruktosa } \\
(+)\end{array}$ \\
$\begin{array}{l}\text { Nelson- } \\
\text { Somogyi }\end{array}$ & Bening & Biru & $\begin{array}{l}\text { Gula } \\
\text { pereduksi } \\
(+)\end{array}$ \\
\hline
\end{tabular}

Produksi asam levulinat dilakukan dengan mengkonversi inulin menggunakan asam klorida pada variasi suhu reaksi. Tepung inulin yang dipanaskan dalam oven pada variasi konsentrasi suhu reaksi dapat dilihat pada Gambar 1.

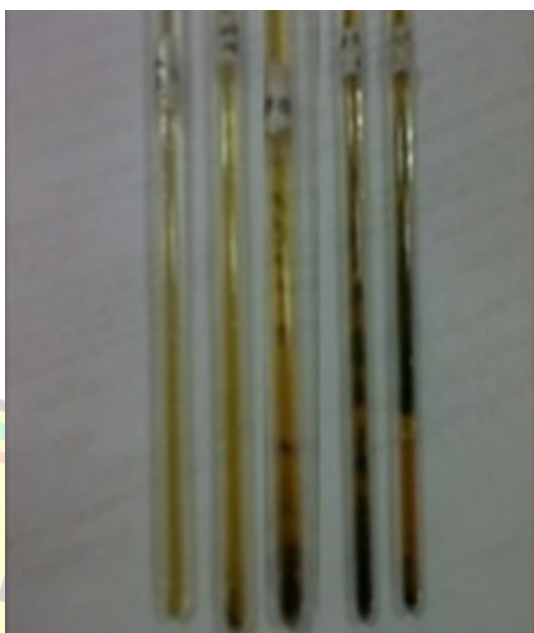

Gambar 1. Pemanasan Sampel Selama 15 Menit dengan Konsentrasi $\mathrm{HCl}$ 0,1 M pada Variasi Suhu Reaksi (Kiri ke Kanan: 130, 140, 150,160 , dan $\left.170^{\circ} \mathrm{C}\right)$.

Berdasarkan gambar 1, semakin tinggi konsentrasi suhu reaksi maka larutan yang semula berwarna putih keabuan akan berubah menjadi kuning muda. Warna kuning akan berubah menjadi lebih pekat mendekati orange dan semakin pekat lagi menjadi kecoklatan yang disertai dengan terbentuknya endapan hitam (humin).

Larutan hasil hidrolisis inulin berada dalam campuran berbagai macam senyawa seperti glukosa, fruktosa, hidroksi metil furfural (HMF), asam levulinat, asam formiat, asamasam organik lainnya, larutan katalis asam klorida dan endapan hitam (humin). Gambar 2 berikut merupakan salah contoh hasil analisis HPLC yang menunjukkan puncak dari senyawa glukosa, fruktosa, $\mathrm{HMF}$, asam formiat dan asam levulinat pada kondisi suhu reaksi $170{ }^{\circ} \mathrm{C}$, asam klorida 0,1 M selama 15 Menit. 


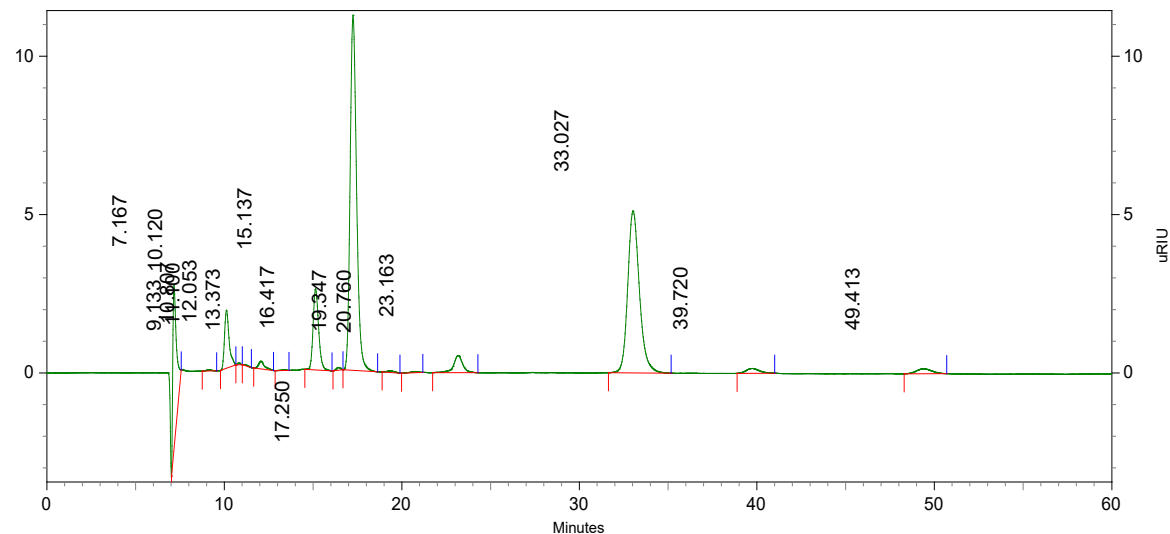

Gambar 2. Kromatogram Larutan Hasil Reaksi pada Pemanasan $170^{\circ} \mathrm{C}$, Konsentrasi Asam Klorida 0,1 M Selama 15 Menit.

Berdasarkan gambar 2, tinggi puncak glukosa (RT 10.120), tinggi puncak fruktosa (RT 11.140), tinggi puncak HMF (RT 33.027), tinggi puncak asam levulinat (RT 17.250) dan tinggi puncak asam formiat (RT 15.137). Jika dibandingkan tinggi puncak asam formiat (RT 15.137) sekitar 1 dengan tinggi puncak asam levulinat (RT 17.250) sekitar 5, dan luas area asam formiat adalah 443438 sedangkan luas area asam levulinat adalah 2257719 , memiliki perbandingan 1:5. Hal ini berarti bahwa asam levulinat lebih dominan dalam larutan hasil reaksi karena molekulnya lebih besar daripada asam formiat, meskipun dalam satuan molar konsentrasi asam levulinat hampir sama dengan asam formiat.

Variasi suhu reaksi. Suhu merupakan salah satu faktor yang penting untuk mengkonversi senyawa-senyawa yang berasal dari biomassa (seperti karbohidrat) menjadi asam levulinat (Yan et al. 2008). Semakin tinggi suhu reaksi maka gerakan molekul-molekul substrat akan semakin kuat, tumbukan sering terjadi dan kecepatan reaksipun semakin cepat sehingga konversi akan semakin besar pula. Hal ini disebabkan pada suhu tinggi, atom-atom melepas dan menerima elektron lebih mudah sehingga meningkatkan peluang terjadinya reaksi kimia (Fang \& Hanna, 2002).

Akan tetapi, peningkatan produk hasil reaksi yang dilakukan melalui peningkatan suhu reaksi kadang-kadang tidak efektif, karena mungkin saja hasil yang diharapkan tidak stabil pada suhu tinggi (Widjadjanti, 2005). Hal ini disebabkan karena adanya glukosa yang pecah menjadi arang (warna larutan hasil semakin tua) (Mastuti \& Ardiana, 2010). Oleh sebab itu, diperlukan suhu yang tepat agar reaksi berlangsung lebih cepat dan menghasilkan produk yang tinggi.

Girisuta (2007) melaporkan bahwa suhu reaksi produksi asam levulinat dari bahan baku fruktosa berkisar antara $100-162{ }^{\circ} \mathrm{C}$, namun berdasarkan pengamatan awal penelitian ini, pada suhu $100-120{ }^{\circ} \mathrm{C}$ tidak terjadi reaksi di dalam ampul (perubahan warna) sehingga variasi suhu dimulai dari $130-170^{\circ} \mathrm{C}$. Pengaruh variasi suhu reaksi dari $130-170{ }^{\circ} \mathrm{C}$ menggunakan asam klorida $0,1 \mathrm{M}$ selama 15 menit terhadap konsentrasi senyawa-senyawa hasil konversi inulin umbi dahlia adalah sebagai berikut:

Glukosa. Pada suhu $130^{\circ} \mathrm{C}-150^{\circ} \mathrm{C}$ konsentrasi glukosa mengalami penurunan (Gambar 3). Penurunan konsentrasi glukosa terjadi karena glukosa telah mulai terkonversi menjadi HMF, namun HMF belum terkonversi menjadi asam levulinat dan asam formiat. Hal ini terbukti dengan tidak ditemukannya produk akhir asam levulinat dan asam formiat (Gambar 7). 


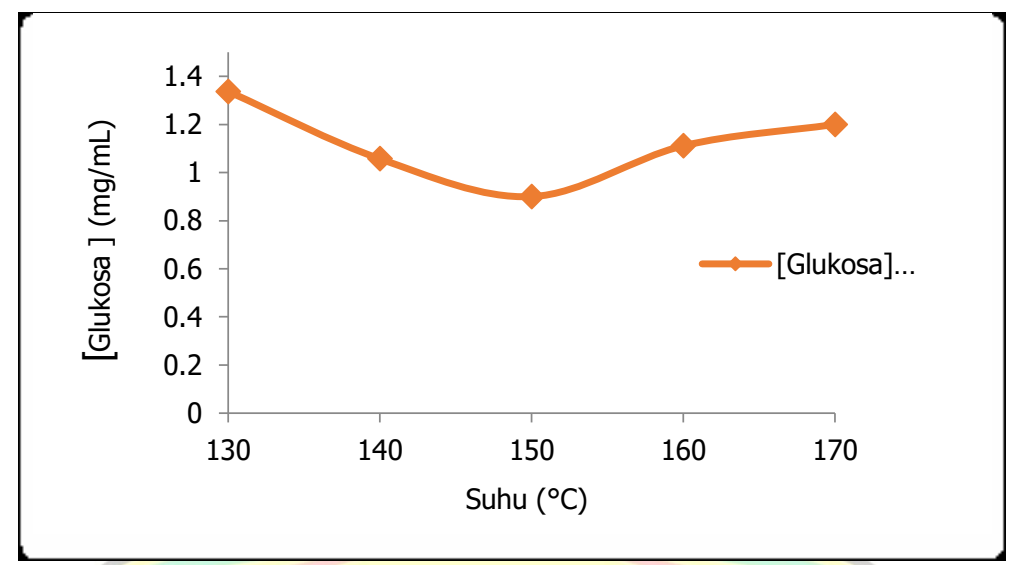

Gambar 3. Hasil Konversi Inulin Menjadi Glukosa Setelah Pemanasan pada Variasi Suhu Reaksi

Akan tetapi, pada suhu lebih dari $150^{\circ} \mathrm{C}$ konsentrasi glukosa kembali naik sampai suhu $170^{\circ} \mathrm{C}$ yaitu dari $0,941 \mathrm{mg} / \mathrm{mL}$ menjadi 1,208 $\mathrm{mg} / \mathrm{mL}$. Kenaikan konsentrasi glukosa ini disebabkan karena senyawa sukrosa yang ada dalam inulin umbi dahlia telah terhidrolisis menjadi fruktosa dan glukosa. Menurut Rachma (2006) sukrosa adalah gula nonreduksi dan stabil terhadap panas. Sukrosa akan berubah atau pecah menjadi dua komponen monosakarida (glukosa dan fruktosa) dalam larutan asam. Reaksi ini akan dipercepat dengan peningkatan keasaman dan peningkatan suhu. Sukrosa jika dipanaskan akan meleleh pada suhu $\pm 160^{\circ} \mathrm{C}$ menjadi larutan yang jernih dan kemudian perlahan-lahan pada suhu $\pm 170^{\circ} \mathrm{C}$ akan berubah menjadi larutan yang berwarna coklat. Proses ini disebut nonenzimatis browning. Pada suhu yang lebih tinggi yaitu antara $190^{\circ} \mathrm{C}-220^{\circ} \mathrm{C}$ terjadi dekomposisi secara lengkap dan menghasilkan karamel. Pemanasan lebih lanjut akan menghasilkan $\mathrm{CO}_{2}, \mathrm{CO}$, asam asetat dan aseton (Rachma, 2006). Selain itu, proses konversi dari glukosa menjadi HMF lebih lambat jika dibandingkan dengan konversi HMF menjadi asam levulinat (Girisuta, 2007), sehingga konsentrasi glukosa yang ditemukan masih tinggi.

Fruktosa. Pada suhu $130^{\circ} \mathrm{C}-170^{\circ} \mathrm{C}$ konsentrasi fruktosa mengalami penurunan (Gambar 4). Penurunan ini terjadi karena fruktosa telah mulai terkonversi menjadi HMF dan selanjutnya asam levulinat. Menurut Nguyen (2008), fruktosa akan mengalami degradasi menghasilkan HMF dengan cepat jika direaksikan dengan asam encer.

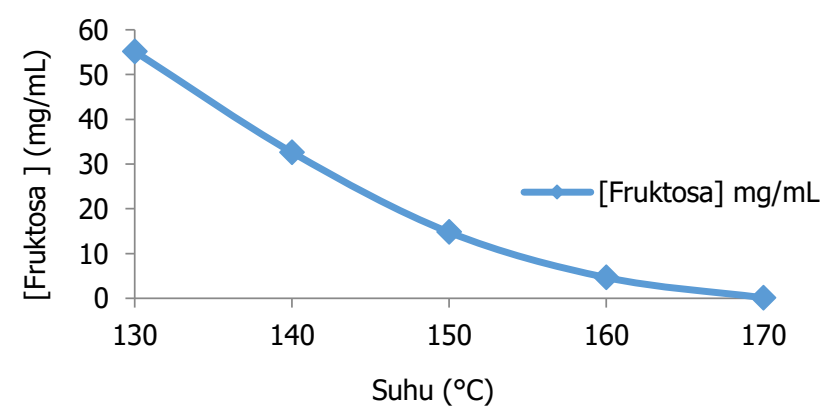

Gambar 4. Hasil Konversi Inulin Menjadi Fruktosa Setelah Pemanasan pada Variasi Suhu Reaksi.

Berdasarkan Gambar 3 dan 4, terdapat perbedaan antara glukosa dan fruktosa. Fruktosa lebih cepat terkonversi menjadi HMF daripada glukosa. Menurut Barklay et al (2010), inulin apabila dihidrolisis dengan air atau asam akan mengalami pemotongan pada ikatan glikosidik. Ikatan glukosa-fruktosa Inulin 4-5 kali lebih tahan terhadap hidrolisis asam daripada ikatan fruktosa-fruktosa, sehingga fruktosa lebih dahulu lepas daripada glukosa. Selain itu, bila dibandingkan dengan stabilitas glukosa, fruktosa 40 kali lebih rentan terhadap 
degradasi asam encer pada suhu tinggi dan hampir 90\% degradasi fruktosa menghasilkan HMF, asam levulinat dan asam formiat. Fruktosa menghasilkan lebih banyak HMF daripada glukosa karena fruktosa memiliki stuktur cincin yang tidak stabil dan sering membentuk cincin terbuka sehingga lebih cenderung mengalami enolasi, sedangkan glukosa memiliki struktur cincin yang stabil dan fraksi cincin terbuka dalam larutan lebih sedikit sehingga enolasi relatif lebih rendah.
Asam Levulinat. Pada suhu $140^{\circ} \mathrm{C}$ konsentrasi asam levulinat yang diperoleh masih sangat sedikit (Gambar 5). Hal ini disebabkan karena pada waktu reaksi 15 menit, fruktosa hasil hidrolisis baru terkonversi menjadi HMF dan masih sedikit sekali yang terkonversi menjadi asam levulinat. Namun, pada suhu reaksi $150^{\circ} \mathrm{C}$ dianggap memberikan energi yang cukup untuk mengkonversi HMF menjadi asam levulinat dan asam formiat.

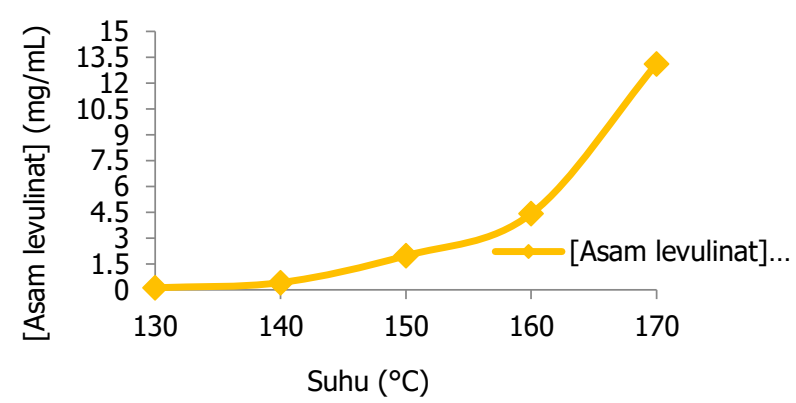

Gambar 5. Hasil Konversi Inulin Menjadi Asam Levulinat Setelah Pemanasan pada Variasi Suhu Reaksi.

Berdasarkan gambar 5, konsentrasi asam levulinat yang diperoleh dari suhu $140^{\circ} \mathrm{C}-170^{\circ} \mathrm{C}$ berkisar antara $0,85 \%$ hingga $26 \%$. Perolehan konsentrasi asam levulinat tersebut dianggap masih rendah. Jika suhu dinaikkan di atas $170^{\circ} \mathrm{C}$ kemungkinan perolehan konsentrasi asam levulinat akan terus meningkat. Akan tetapi, karena keterbatasan peneliti suhu reaksi tertinggi yang digunakan untuk memproduksi asam levulinat pada penelitian ini hanya sampai $170^{\circ} \mathrm{C}$.

Asam Formiat. Pada suhu $130^{\circ} \mathrm{C}-170^{\circ} \mathrm{C}$ konsentrasi asam formiat meningkat dengan semakin tingginya suhu reaksi (Gambar 6). Asam formiat merupakan hasil sampingan dari konversi glukosa dan fruktosa menjadi asam levulinat pada suhu tinggi dengan katalis asam. Pola kenaikan konsentrasi asam formiat hampir sama dengan pola kenaikan asam levulinat. Hal ini disebabkan karena dalam setiap reaksi konversi HMF menjadi asam levulinat selalu melepaskan 1 molekul asam formiat, namun konsentrasi asam formiat yang dihasilkan lebih rendah daripada asam levulinat dalam satuan berat $(\mathrm{mg} / \mathrm{mL})$.

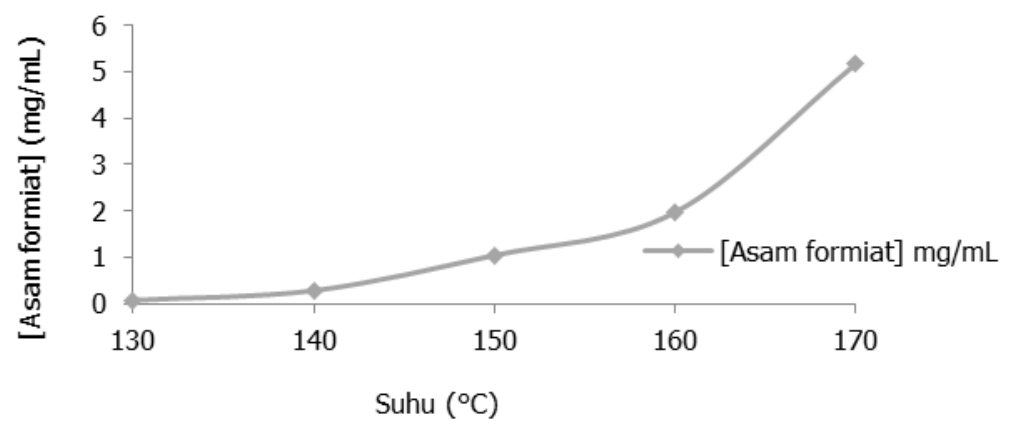

Gambar 6. Hasil Konversi Inulin Menjadi Asam Formiat Setelah Pemanasan pada Variasi Suhu Reaksi.

Pengaruh suhu terhadap konsentrasi masing- levulinat dan asam formiat dapat dilihat pada masing senyawa glukosa, fruktosa, asam diagram gabungan Gambar 7 berikut. 
Berdasarkan gambar 7, suhu pada proses konversi inulin sangat berpengaruh terhadap perolehan asam levulinat. Konsentrasi asam levulinat cenderung meningkat dengan semakin meningkatnya suhu reaksi.

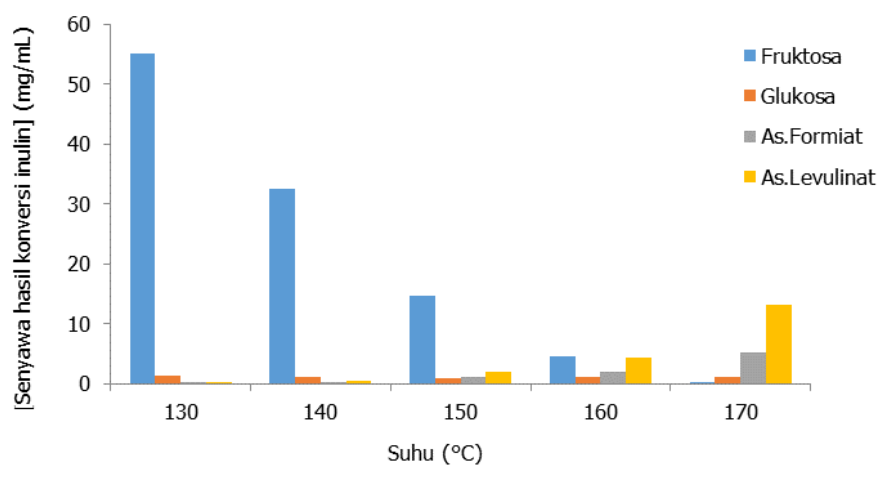

Gambar 7. Diagram Konsentrasi Masing-masing Senyawa Hasil Konversi Inulin pada Variasi Suhu Reaksi Selama 15 Menit dengan Konsentrasi HCl 0,1 M.

\section{KESIMPULAN}

Kadar inulin yang diperoleh dari $100 \mathrm{~g}$ umbi dahlia segar sebesar $4 \%$ (b/b umbi dahlia). Kadar asam levulinat yang diperoleh menggunakan substrat inulin $5 \%$ pada pemanasan $170^{\circ} \mathrm{C}$ konsentrasi asam klorida 0,1 M selama 15 menit adalah $26,25 \%$ (b/b inulin). Produksi asam levulinat sangat dipengaruhi oleh faktor suhu reaksi.

\section{UCAPAN TERIMA KASIH}

Ucapan terima kasih disampaikan kepada Bapak Prof. Dr. Saryono, M.Si dan Bapak Prof. Dr. Amir Awaluddin, M.Si selaku tim yang telah membiayai penelitian ini dari Dana Hibah Insidental dengan No.331/UNlg-2/PL2011.

\section{DAFTAR PUSTAKA}

Andyani, N.F. (2001). Produksi sirup fruktosa dari inulin dahlia pinnata cav. secara hidrolisis asam. Skripsi. Jurusan Teknologi Industri Pertanian. FATETAIPB.

Barklay, T., Markovic, M.G., Cooper, P \& Pertovsky, N. (2010). Inulin-A versatile polysaccharide with multiple pharmaceutical and food chemical uses. $J$ Excipient and Food Chem 1(3): 27-50.

Bozell, J.J., Moens, L., Wang, Y., Neuenswander, G.G., Fitzpatrick, S.W., Bilski, R.J \& Jarnefeld, J.L. (2000). The Use of Renewable Feedstocks for the
Production of Chemicals and Materials. National Renewable Energy Laboratory 1617 Cole Boulevard Golden, CO 8040.1.

Fang, Qi \& Hanna, M.A., (2002). Experimental Studies of Levulinic Acid Production From Whole Kernel Grain Shorgum. Industrial Agricultural Products Center, University of Nebraska. Lincoln. NE 68583-0730, USA. Bioresource Technology 81 (187-192).

Girisuta, B. (2007). Levulinic Acid from Lignocellulosic Biomass. University of Groningen. ISBN 978-90-367-3228-4.

Hariono, M., Akbar, M.F., Sularsih, I., Najihah, L., Purwadi, S \& Nugrahani, A.W. (2009). Extraction, identification and acetylation of inulin from Dahlia tuber (dahlia pinata cav.). The 9th National Symposium on Polymeric Materials NSPM.

Mastuti, E. \& Ardiana., S., (2010). Pengaruh Variasi Temperature dan Konsentrasi Katalis Pada Kinetika Reaksi Hidrolisis Tepung Kulit Ketela pohon. Jurusan Teknik Kimia. Teknik Universitas Sebelas Maret. Ekuilibrium Vol 9. No. 1. Hal 23-27.

Nguyen, S.K. (2008). Hydrolytic Methods for the Quantification of FructoseEquivalents in Herbaceous Biomass. Tesis. Oregon State University. 
Rachma., A., (2006). Kajian Pengaruh Suhu, pH, Waktu dan Konsentrasi Inhibitor Akar Kawao (Milletia sericea) pada Degradasi Sukrosa oleh Invertase. Fakultas Teknologi Pertanian IPB. Bogor Rahayuningsih, M \& R. Purnawati. (1993). Perbaikan Konversi Mikrobial Inulin menjadi Fruktosa. di dalam Susdiana, Y. 1997. Ekstraksi dan karakterisasi inulin dari umbi dahlia (Dahlia pinnata Cav). Skripsi, unpublished. Fakultas Teknologi Pertanian, Institut Pertanian Bogor.

Robertfroid, M.B. (2005). Introducing inulintype fructans. British Journal of Nutrition 93(1): S13-S25.

Simanjuntak., Rachmat., \& J. Rosalinda, N., (2004). Tumbuhan Indonesia Sebagai Sumber inulin. Pusat Penelitian Bioteknologi-LIPI. Alchemy. Vol. 3 No. 1. 8-14.

Widjajanti., E., (2005). Pengaruh Katalisator Terhadap Laju Reaksi. Makalah
Pengabdian pada Masyarakat. FMIPA. UNY. Yogyakarta

Widowati, Sunarti, T.C \& Zaharani, A. (2005). Ekstraksi, karakterisasi dan kajian potensi inulin dari umbi dahlia (Dahlia pinnata L.). Makalah Seminar Rutin Puslitbang Tanaman Pangan, Bogor, 16 Juni 2005.

Winarno, F.G. (1997). Kimia Pangan dan Gizi. Jakarta : PT. Gramedia Pustaka Utama.

Yan, L., Yang, Naikun, Pang, H. \& Liao, B. (2008). Production of Levulinic Acid from Bagasse and Paddy Straw by Liquefaction in the Presence of Hydrochloride Acid. Research Article. Department of Chemical Physics, Hefei National Laboratory for Physical Science at Microscale, University of Science and Technology of China, Hefei, $P . \quad R$. China. DOI:10.1002/clen.200700100.36 (2): 158-163. 